\title{
O DELÍRIO DAS MÁQUINAS: A PRODUÇÃO DE IMAGENS EM O PROCESSO
}

\section{THE MACHINES DELIRIUM: THE PRODUCTION OF IMAGES IN THE TRIAL}

\author{
Thiago Ranniery' \\ Baruc Carvalho Martins ${ }^{2}$
}

\begin{abstract}
RESUMO: Compor um protocolo de experiência ao invés de uma experimentaçáo interpretante ou significante; agarrar o mundo ao invés de extrair-lhe impressōes. A literatura de Franz Kafka, como nos lembra Deleuze e Guattari (2003), é uma máquina de expressâo que opera em diversos graus, tanto por expressōes e conteúdos formalizados quanto por expressóes nâo formalizadas e conteúdos puros. Essa máquina, assim, excederia a representaçâo para atingir também o caráter genético da linguagem, ao mesmo tempo constituindo imagens e promovendo novas fraturas na distância mesma que as produz. Com este artigo, propomo-nos a analisar, a partir da trilha aberta por Deleuze e Guattari, a produçấo de imagens no romance O Processo (2008), argumentando, em articulaçăo com a taxonomia das imagens do cinema feita por Deleuze, que o anti-estetismo de Kafka atua diretamente para conectar palavra e imagem com o objetivo de seguir uma vontade de escrita que constitui a própria potência da palavra.
\end{abstract}

Palavras-chave: Kafka; literatura; imagem; máquina.

ABSTRACT: Making tests of experience rather than interpreting or signifying experimentation; Grabbing the world instead of taking its impressions. Franz Kafka's literature, as Deleuze and Guattari remember us, is an expression machine that works in many levels: in expressions an d formalized contents as well as unformalized expressions and pure contents. This machine would exceed representation to reach the genetic side of language and would constitute images and promote new fissures while produces itself. This article examines the production of images in the novel The Trial (2008), based in Deleuze and Guattari theories. We indicate, in articulation with

Professor do Programa de Pós-Graduaçâo em Educaçăo e da Faculdade de Educaçăo da Universidade Federal do Rio de Janeiro (FE/UFRJ). Doutor em Educaçâo pela Universidade do Estado do Rio de Janeiro (UERJ) e Mestre em Educaçâo pela Universidade Federal de Minas Gerais, é pesquisador do Núcleo de Estudos de Currículo (NEC/FE/UFRJ) e do grupo de pesquisas Currículo e Diferença (Proped/UERJ), com investigaçōes sobre currículo, ética e políticas da ontologia.

2 Jornalista pela Universidade Federal de Sergipe (UFS), cineasta, mestrando do Programa de PósGraduação em Estudos da Literatura da Universidade Federal Fluminense (UFF) e graduando em Letras Literaturas pela mesma universidade. Realizou dois documentários e atualmente trabalha na produçáo executiva da adaptaçăo cinematográfica de um conto de Antônio Carlos Viana. 
Deleuze's taxonomy of images, that the anti-aesthetic of Kafka's literature connects word and image according with the wish of writing that is part of the power of word itself.

Keywords: Kafka; literature; image; machine.

Numa manhă, após a visita de alguns funcionários do tribunal, Joseph K. iniciou o processo. Passando pela contiguidade de quartos e salas; pelas figuras estranhas de personagens que quase - assim como K. - finalizam uma açâo ou reaçăo; K., essa abreviaçâo apagada de um nome familiar - perversa relaçăo que Kafka e K. estabelecem -, enfrenta a máquina burocrática do tribunal no seu próprio funcionamento. É fabricada a cena: terrível sina de um homem às voltas com a imanência da lei, do que pode suas conexóes num campo de atuaçăo que recobre todo o mundo sem nunca estar fechado a ele. Se a procura de K. é por alguma saída, uma fratura adjacente na máquina - ou nas máquinas que se acoplam, sobrepassam, forjam novas relaçôes no desenrolar do romance -, é porque ele, K., já participa dela, como uma engrenagem, uma roda dentada, da grande máquina do Fora de O Processo.

$\mathrm{K}$. é essa figura estranha que faz delirar as máquinas. O processo e K. săo indissociáveis, assim como antiproduçáo e produção, forma e força, micropolítica e macropolítica. Há em O Processo essa política que Kafka, maquinando K. com sua máquina de expressăo, constitui bem: uma vida intensiva como modo de escrever diretamente no real. Diferente, por isso, de qualquer reduçáo da política à instituiçáo ou à linguagem. A máquina de $\mathrm{K}$. é, assim, anterior e, ao mesmo tempo, imanente ao próprio $\mathrm{K}$; pois, como nos lembra Deleuze e Guattari, "antes do ser, há a política" (DELEUZE; GUATTARI, 1996, p. 78). Uma política que já é imediatamente prática e opera a partir de comunicaçăo por contágio. Imediata. Ainda que haja um retorno em K., promovido pelo balançar entre dois polos (o polo esquizo e o paranoico/edipiano), o perigo se estabelece sempre pela fixaçâo. Desligar a máquina de $\mathrm{O}$ Processo, ao contrário da máquina arcaica de $\mathrm{Na}$ Colônia Penal, nâo é uma opçâo desejável:

Porque toda a história de K. é a maneira como ele mergulha progressivamente no adiamento ilimitado, violando as fórmulas da absolviçăo aparente. Deste modo, ele sai da máquina abstrata da lei, que opóe a lei ao desejo como o espírito ao corpo, como a forma à matéria, para entrar no agenciamento maquínico da justiça, isto é, na imanência mútua de uma lei descodificada e de um desejo desterritorializado. (DELEUZE; GUATTARI, 2003, p. 93)

É o desejo, e năo a lei, que invade todo o campo. A lei só aparece a partir desse agenciamento, dessas conexóes que săo forjadas. Além disso, para que haja lei é preciso, ainda, que haja a produçâo concreta de um enunciado. O enunciado produz a lei que se efetua no castigo, se inscreve no corpo, na carne. A lei é, por isso, "enunciado prático que se opóe a qualquer proposta especulativa" (op. cit., p. 82). Năo se trata, portanto, de uma transcendência da lei, mas de uma imanência (op. cit., p. 92). De tal modo que, "onde se julgava que havia lei, há, de facto, desejo e apenas desejo. A justiça é desejo, e nâo é lei" (op. cit., p. 89). Também náo há Necessidade, mas Acaso (op. cit., p. 90). É a força da contingência que, tomada além de qualquer determinismo, apresenta-se movida pela sobriedade das palavras de Kafka. Algo se passa, entăo, numa espécie de fundo semfundo de $O$ Processo que excede qualquer profundidade em sua própria superfície. Um 
deslocamento aqui nos é possível: é a força decisiva da superfície, do que aparece, do que se forja enquanto simulacro, que é convocada. Pois o processo só é possível nesse movimento interminável de ligar novas máquinas, produzir novas conexōes. O contrário disso é a morte. Mas năo a morte local e necessária para o devir. Trata-se, porém, da morte do Fora, "que nos leva e nos destrói" (LAPOUJADE, 2015, p. 315).

E que máquinas săo essas? Săo máquinas de todos os tipos: máquinas burocráticas, capitalistas, libidinais... máquinas de máquinas que operam com a fabricaçăo e reelaboraçāo de limites, cortes, passagem de fluxos. Máquinas que se forjam a partir do desejo e que já é, ao mesmo tempo, imediatamente social. Desde $O$ Anti-Édipo (2004), Deleuze e Guattari nos apresentam essa noçăo numa crítica direta ao Imaginário freudiano e ao Significante lacaniano. O desejo, aqui, é entendido como produçăo de realidade; e, se há máquinas sociais que atuam ao nível molar, também há, correlativamente, máquinas desejantes que operam numa dimensăo distinta daquela e a constituem sub-repticiamente. Molar e molecular, por isso, sâo duas dimensôes para uma mesma operaçăo. É esse conjunto de máquinas heterogenéticas (tanto do ponto de vista dos elementos que as compóem quanto da abertura à processualidade) que fazem do inconsciente uma usina.

A esquizo-análise renuncia a qualquer interpretaçăo porque renuncia deliberadamente a descobrir um material inconsciente: o inconsciente năo quer dizer nada. Mas, pelo contrário, ele faz máquinas que săo as do desejo e cujo funcionamento e utilizaçăo a esquizo-análise descobre na sua imanência às máquinas sociais. O inconsciente năo diz nada, maquina. Năo é nem expressivo nem representativo, mas produtivo. Um símbolo é apenas uma máquina social que funciona como máquina desejante, uma máquina desejante que funciona na máquina social um investimento da máquina social pelo desejo. (DELEUZE; GUATTARI, 2004, pp. 186-187)

Em O Processo, a máquina de expressāo, ou máquina literária, de Kafka possui uma particularidade frente a outras máquinas presentes em obras anteriores: nesta, a própria aparente unidade é colocada em questăo, pois "já năo há nenhuma diferença entre estar fora ou dentro" (DELEUZE; GUATTARI, 2003, p. 27). Personagens, objetos e lugares estăo de tal modo articulados que todos eles funcionam como peças da máquina - que já săo máquinas - de O Processo. É à desmontagem/montagem do agenciamento concreto que servem. Pois, se nas novelas havia um limite para essas conexóes, é com os romances que Kafka resolve esse impasse a partir do próprio modo de funcionamento do agenciamento concreto (op. cit., pp. 69-70).

Convém lembrar que Deleuze e Guattari apontam, ainda, três instâncias na máquina kafkiana - índices maquínicos, máquinas abstratas e agenciamentos concretos - que corresponderiam, respectivamente, às cartas, às novelas e aos romances. Essa correspondência, todavia, nâo apontaria para uma mútua exclusăo entre essas instâncias, mas, mais uma vez, a um tipo específico de processualidade da máquina literária em cada uma dessas obras. Com efeito, essas três instâncias também sâo coextensivas e sobreinvestidas entre si, diferindo apenas em como essas forças săo captadas para a criaçăo artística. O agenciamento, assim, diferiria da máquina por se instalar no próprio processo de montagem/desmontagem, no entre que se desenvolve entre eles, deixando sempre aberto esse processo a partir de novas conexóes que forjaria, 
antecipando-se às atualizaçôes e às representaçōes de qualquer tipo. O que impediria também, dessa forma, a constituiçâo de uma crítica social - esta, já demasiadamente representativa, demasiadamente humana:

Por fim, o agenciamento náo vale como uma máquina que está a ser montada, com um funcionamento misterioso, nem como uma máquina já montada, que năo funciona ou que já năo funciona: só vale pela desmontagem que faz da máquina e da representaçăo, e ao funcionar atualmente, só funciona por e dentro da sua própria desmontagem. Nasce dessa desmontagem (Kafka nunca se interessou pela montagem da máquina). Este método de desmontagem ativa năo passa pela crítica que pertence ainda à representaçăo. Consiste, antes, em prolongar, em acelerar exatamente um movimento que já atravessa o campo social. Opera num virtual, que já é real sem ser atual (as forças diabólicas do futuro que pelo momento só batem à porta). (op. cit., p. 88)

Nesse sentido, a incerteza ou incompletude em que sempre ficam as açóes de $\mathrm{K}$. e dos personagens auxiliam nessa operaçăo de dar espessura a essa abertura, tendo como um elemento muito presente o quase que configura nâo só essas açôes como também participa de toda a narraçấo - exemplo disso é o quase conhecimento do processo pelos inspetores de K. (KAFKA, 2008, p. 26) -, sendo constitutivo dessa vontade de escrita colocada a termo em 0 Processo.

\section{Abrindo as máquinas para novas máquinas}

No primeiro capítulo de Kafka - para uma literatura menor, Deleuze e Guattari retomam o problema do plano de expressâo e de conteúdo de Hjelmslev, que também estava vivo em $O$ Anti-Édipo e Mil Platôs, a partir de mais uma fratura sensível. Dessa vez, para pensar como em Kafka a máquina literária operava uma desterritorializaçâo que permitia atingir conteúdos puros, Deleuze e Guattari partem da articulaçăo cabeça inclinada (forma de conteúdo) e retrato-fotografia (forma de expressăo) presente no início de Castelo para mapear uma outra articulaçăo, completamente distinta, entre cabeça erguida e som musical, presente em várias obras do autor (Castelo; Metamorfose; Descriçâo dum combate; Pesquisas dum câo; Josefina, a cantora ou o Povo dos ratos; América). Constituída essas duas relaçóes cabeça inclinada/retrato-fotografia e cabeça erguida/som musical, eles observam:

Esses exemplos bastam para mostrar que o som năo se opóe ao retrato na expressáo, como, no conteúdo, a cabeça erguida se opóe à cabeça inclinada. Entre as duas formas de conteúdo, se as considerarmos abstratamente, há uma oposiçăo formal simples, uma relaçăo binária, uma característica estrutural ou semântica, que năo nos faz, precisamente, sair do (significante), e conduz mais à dicotomia do que ao rizoma. Contudo, se, por sua vez, o retrato já é uma forma de expressáo que corresponde à forma de conteúdo (cabeça inclinada), já năo é o mesmo com o som. O que interessa a Kafka é uma pura matéria sonora intensa, continuamente em relaçăo com a sua própria aboliçâo, som musical desterritorializado, grito que escapa à significaçâo, à composiçấo, ao canto, à palavra, sonoridade em ruptura a fim de escapar a uma sujeiçấo ainda demasiado significante. No som, só conta a intensidade, em geral monótona, sempre insignificante. (DELEUZE; GUATTARI, 2003, p. 23) 
Dessa forma, é o som, enquanto intensividade e năo como música semioticamente formada, que fará a cabeça erguida se colocar como conteúdo puro. Pois o som nâo aparece nessas obras como forma de expressâo, "mas precisamente como uma matéria de expressâo nâo formada que vai reagir sobre os outros termos" (op. cit., p. 24). É essa estranha sinfonia produzida, a cada vez, entre expressâo e conteúdo formalizados e expressōes nâo formalizadas e conteúdos puros que Kafka conduzirá a sua escrita.

Onde estariam as máquinas nesse jogo entre expressăo e conteúdo? Em toda parte. Assim como os índices maquínicos, as máquinas abstratas e os agenciamentos concretos săo coextensivos; a dupla articulaçâo entre expressăo e conteúdo também já participa desde sempre dessas operaçôes, ordenando e organizando os estratos que fazem a ligaçăo entre a máquina abstrata - tomada aqui năo como a máquina abstrata "transcendente e reificada" de Na colônia penal (op. cit., p. 145), mas como um nível de percepçăo da realidade - e o agenciamento concreto (LAPOUJADE, 2015, pp. 203-204). Porém, mesmo nessa articulaçăo ao nível dos estratos, estamos lidando com formas. Convém, por isso, ter maior cuidado ao que Deleuze e Guattari apontam quanto à funçâo do som, do papel estratégico da expressâo para o efeito de conjunto, liberando tanto a própria expressâo quanto o conteúdo de suas relaçóes ainda demasiadamente formalizadas, ainda demasiadamente humanas. Pois é a "expressăo que nos dá o procedimento" (DELEUZE; GUATTARI, 2003, p. 38). É a partir da expressâo que Kafka faz o seu maior investimento enquanto projeto de escrita, fazendo funcionar a máquina delirante e sempre aberta - ainda que advenham os problemas de sua ediçâo feita por Max Brod, sobretudo quanto ao capítulo final - de O Processo.

As três instâncias da máquina literária de Kafka estăo conjugadas em O Processo: com os índices maquínicos, as máquinas abstratas e o agenciamento concreto. Todos os personagens, lugares, objetos e paisagens sâo agentes, o próprio K. é um agente, à serviço da imanência da justiça. E se há uma loucura no movimento de toda essa maquinaria infernal, desses personagens esquisitos em situaçōes absurdas, é porque o que está em jogo săo os fluxos esquizos, as linhas de fuga dada pelos animais - no caso, principalmente, das novelas - ou pelas mulheres - no caso, por exemplo, de 0 Processo. O que năo quer dizer, de forma alguma, que as personagens femininas sejam arquétipos ou metáforas de quaisquer coisas. O que há, frise-se, é uma comunicaçấo direta entre palavra e imagem, a palavra dando origem à imagem.

Kafka aniquila deliberadamente toda e qualquer metáfora, simbolismo, significaçăo, assim como qualquer designaçăo. A metamorfose é o contrário da metáfora. Já năo há sentido próprio nem figurado, mas uma distribuiçâo de estados no leque da palavra. A coisa ou as outras coisas sâo apenas intensidades percorridas pelos sons ou pelas palavras desterritorializadas conforme as suas linhas de fuga. (op. cit., pp. 47-48)

Rachar as palavras e as coisas para extrair delas os enunciados. Eis uma espécie de procedimento aplicado por Kafka que em muito se assemelha ao defendido por Michel Foucault a partir de uma leitura deleuzeana (DELEUZE, 2005, p. 61). Mas é justamente nesse momento que tudo muda porque atinge um limiar em que as palavras e as imagens - tudo o que se diz e tudo o que pode ser visto - estâo tăo próximas que só há distância e é essa distância que define a palavra e a imagem enquanto as mantém envolvidas numa relaçâo que é só relaçăo: 
Mas, assim que abrimos as palavras e as coisas, assim que descobrimos os enunciados e as visibilidades, a fala e a visăo se alçam a um exercício superior, a priori, de forma a cada um atingir seu próprio limite que a separa da outra, um visível que tudo o que pode é ser visto, um enunciável que tudo o que pode é ser falado. E, entretanto, ainda, o limite próprio que separa cada uma é também o limite comum que relaciona uma à outra e que teria duas faces assimétricas, fala cega e visăo muda. Foucault está singularmente próximo do cinema contemporâneo. (DELEUZE, 2005, p. 74, grifo nosso)

Kafka opera, por isso, num nível distinto da representaçăo, dos conteúdos e expressōes formalizados, pois o que está em jogo nessa vontade de escrita é o desejo a partir da pura virtualidade que já é real sem nunca se atualizar. De modo que, como já dissemos, há uma defasagem constitutiva que é necessária para a heterogênese de 0 Processo. Esse, inclusive, é o ponto nevrálgico da argumentaçấo de Deleuze e Guattari sobre a máquina kafkiana que gostaríamos de levar um pouco mais adiante para pensar a questăo das imagens.

\section{Imagens e desafios para uma literatura menor}

Escrever é devir, como nos lembra Deleuze (1997) no célebre texto "Literatura e Vida". Ainda que a literatura possa fazer uso de uma linguagem extensiva ou representativa, e que haja uma literatura maior, a escrita sempre nos coloca em um devir, nos abre a novas desterritorializaçōes. Em Kafka, há uma tentativa incessante pelo adiamento ilimitado com o objetivo, mesmo que nem sempre tăo claro, de acessar a pura potência da escrita. Todos os escritos, cartas, novelas, romances, diários, fazem parte da obra ainda que náo estejam presentes nela. Porque é com as conexóes do rizoma e com a força criativa da linha de fuga que Kafka leva adiante a produçấo de novas máquinas - sendo ele mesmo também uma máquina a se conectar, acoplar, fazer fugir o conjunto (DELEUZE; GUATTARI, 2003, pp. 77-78).

De maneira análoga, por isso, essa operaçăo também se repete com a constituiçăo das imagens. Já que năo busca metáforas, simbolismos nem arquétipos, o que a literatura dá a ver săo fragmentos de códigos ao invés de reproduçâo de imagens (op. cit., p. 35). $\mathrm{O}$ que năo quer dizer, porém, que nâo haja imagens extensivas, dispostas entre personagens, lugares e paisagens. Mas que há uma agitaçáo molecular constante que envolve modos outros de temporalizaçăo da escrita, convocando novas forças e deixando sempre em aberto essas imagens para novas e constantes formaçōes. É a essa defasagem que corresponde a pura virtualidade de O Processo. Mesmo porque, a palavra só pode conectar-se à imagem sob o preço de tanto palavra quanto imagem já estarem cindidas, instaladas em seu próprio intervalo.

Um fenômeno semelhante, ainda que năo igual, é visto com as imagens audiovisuais. É a partir dessa operaçăo que, inclusive, distingue a imagem-movimento, matéria específica do cinema, da imagem-tempo, que teremos condiçóes de pensar năo só a abertura da máquina literária de Kafka como também a proliferaçâo de suas conexôes. Segundo Deleuze (1983), a partir das pesquisas de Henri Bergson em Matéria e Memória, nâo nos é possível manter a dicotomia entre o movimento, como a realidade física no mundo exterior, e a imagem, como realidade psíquica na consciência. Pois a imagem já é movimento, participando dele e sendo por ele investida. É, nesse sentido, também, que 
a imagem opera um movimento de duas faces - uma voltada para o conjunto e suas partes e outra para o todo e suas mudanças -, apresenta-se como imagem-movimento e é, desde já, matéria, afirmando-se como o "conjunto daquilo que aparece" (DELEUZE, 1983, p. 71). Precisamente aqui, há uma aproximaçăo de Deleuze com os sofistas. Em Diferença e Repetiçâo (1988), o próprio Deleuze promove uma reversăo do platonismo ao colocar o simulacro como sistema diferencial do eterno retorno - este último, também já virado do avesso pelo filósofo a partir de Nietzsche. Nâo existindo mais original nem derivado e, por correlaçăo, fazendo coro com o Estrangeiro de O Sofista (2003) - à revelia e, ao mesmo tempo, com o próprio Platăo -, ao pensar o náo-ser como já ser e o ser, em certa medida, como náo ser. A consequência é a anulaçâo da oposiçáo ser e năo ser, sustentada na teoria das imagens platônicas, que discerniria as imagens verdadeiras das imagens falsas. As imagens, por isso, seriam aparência e matéria em uma relaçăo constituinte com o corpo (que já é um tipo de imagem específica) - onde se atualizariam.

Todavia, quando um corte irracional opera no intervalo do Todo Aberto da imagemmovimento, produz-se um Todo Fora, fabricado no interstício das imagens que a constituem - sendo elas, entre si, imanentes e coextensivas (DELEUZE, 2005). É, por isso, nessa substituiçáo da imagem-açáo, do vínculo sensório-motor, para as imagens óticas e sonoras puras que será possível ao cinema mostrar o tempo diretamente. A imagemtempo seria produzida, assim, na distância mesma que constitui a imagem-movimento, liberando suas forças para novas e incessantes conexóes. Deleuze aponta, ainda, duas imagens-tempo diretas a partir de Bergson: uma fundada no passado (coexistência dos lençóis do passado) e outra fundada no presente (simultaneidade das pontas do presente). A essa primeira imagem, corresponderia a ideia de um cone revertido. Dessa forma, o passado, enquanto lembrança pura, imagem virtual que náo se atualiza, seria, no tempo, colocado para atualizar-se em uma imagem-lembrança que só se estabeleceria em relaçáo com o passado pelo próprio movimento de buscar o passado. Já a outra imagem tempo direta, essa é a que particularmente nos interessa, ao contrário dos aspectos, lida com acentos e está particularmente envolvida náo pelo presente que passa, mas pela simultaneidade do presente que náo obedece mais ao tempo cronológico. 0 modo do tempo se dá agora por Aion, e nâo mais por Cronos. Diz Deleuze:

Na bela fórmula de Santo Agostinho, há um presente do futuro, um presente do presente, um presente do passado, todos eles implicados e enrolados no acontecimento, portanto, simultâneos, inexplicáveis. Do afeto ao tempo: descobrimos um tempo interior ao acontecimento, que é feito da simultaneidade dos três presentes implicados, dessas "pontas de presente" desatualizadas. É a possibilidade de tratar o mundo, a vida, ou simplesmente uma vida, um episódio, como um único e mesmo acontecimento, que funda a implicaçăo dos presentes. Um acidente vai acontecer, acontece, aconteceu; mas também é ao mesmo tempo que ele vai ocorrer, já ocorreu, está ocorrendo; de modo que, devendo ocorrer, ele năo ocorreu, e, ocorrendo, năo ocorrerá... etc. É o paradoxo da camundonga Josefina em Kafka: ela canta, cantou, cantará, ou entăo nada disso, embora tudo isso produza diferenças inexplicáveis no presente coletivo dos camundongos? É ao mesmo tempo que alguém năo tem mais a chave (quer dizer que a tinha), ainda a tem (năo a havia perdido) e a encontra (quer dizer, ele a terá e năo a tinha). (DELEUZE, 2005, p. 124, grifo do autor) 
Todavia, mesmo que essa imagem provoque uma aberraçáo do movimento, ela náo suprime a narraçăo. Mas, pelo contrário, e "o que é bem mais importante, ela confere à narraçăo novo valor" (op. cit., p. 125) ao abstraí-la de seu vínculo sensório-motor. Com efeito, essa narraçăo "vai consistir em distribuir os diferentes presentes às diversas personagens, de modo que cada uma forme uma combinaçăo plausível, possível em si mesma, mas que todas em conjunto sejam 'incompossíveis', e que o inexplicável seja por isso mesmo mantido, suscitado" (op. cit., p. 125).

Há um outro fator apontado por Deleuze ao nível das descriçōes que nos é particularmente importante para pensar uma articulaçăo com O Processo: trata-se das potências do falso que sáo convocadas para substituir a imagem-açáo, presente e imanente à imagem-movimento, por imagens óticas e sonoras puras. Fazendo uma análise da narraçăo cinematográfica e observando a maneira como Deleuze concebe as imagens do cinema, André Parente (2000) promove uma atualizaçăo do problema das imagens à luz do próprio conceito de acontecimento de Deleuze, defendendo que a imagem năo é primeira frente à narrativa - e esta já năo é uma operaçăo linguística -, mas que ambas săo consubstanciais (em boa parte dos casos, com exceçăo, por exemplo, do cinema năo-narrativo, instalado no outro regime de imagem proposto por Bergson: gasoso, da variaçấo universal). Com efeito, a imagem assume plenamente o papel de acontecimento e constitui-se, com exceçấo do cinema năo narrativo, a partir de processos imagético-narrativos. Por essa via, conforme o modo de temporalizaçăo e de apresentaçăo das imagens do real (imagem-movimento e imagem-tempo), teríamos dois modos narrativos: um narrativo verídico e outro náo verídico, disnarrativo ou falsificante. Substituindo a integraçâo, diferenciaçăo e especificaçăo das imagens - como no caso da imagem-movimento -, pela seriaçáo e ordenaçáo - que sáo mobilizadas pela imagem-tempo. Assim, na "narrativa verídica composta de imagens-movimento tudo se reduz ao um, ao passo que, na narrativa falsificante da imagem-tempo, há uma multiplicidade irredutível que afeta o cinema" (PARENTE, 2000, p. 47).

Parente ainda elenca quatro diferenças entre o ato narrativo de presentificaçăo das narrativas nâo-verídicas ou falsificantes e a narraçấo ou narrativa de uma açâo presente ou passada, vista nas narrativas verídicas: 1) Na narrativa năo-verídica o acontecimento náo preexiste à narrativa, pois esse ato de presentificaçấo abre a imagem a um presente vivo (= a qualidade do tempo); 2) Além de imanente ao acontecimento, o ato de narraçâo nâo-verídica remonta o acontecimento do interior (consequentemente coexistência das relaçôes de tempo); 3) Implica uma multiplicidade que afeta as histórias, as personagens e os narradores; 4) Discurso indireto livre profundo, coexistência de "representante" e "representado" (op. cit., pp. 48-49).

Cabe-nos agora, após apresentar essa breve reflexăo a partir das imagens do cinema, fazer uma tentativa, mesmo que modesta, de pensar algumas relaçóes entre esse movimento aberrante que constitui a imagem-tempo e a convocaçâo dessas potências do falso com o movimento que Kafka opera em O Processo para conectar diretamente palavra e imagem. Precisamos, por isso, fazer esse primeiro alerta: ainda que saibamos sobre o risco de pensar essa articulaçăo entre conceitos e objetivos em trabalhos tăo distintos de Deleuze e Guattari, tanto no que se refere à questăo das imagens na literatura em Kafka - para uma literatura menor quanto das imagens do cinema em Cinema 1 e 2, convém notar a sensibilidade desses mesmos autores em 0 que é a 
filosofia? (2010) ao perceber que o que difere a ciência, a filosofia e a arte é a maneira como recortamos o caos - e nâo, como uma tradiçáo mais consolidada nos faz crer, conteúdos (compreendidos enquanto significados) ou campos específicos. Os próprios livros sobre cinema de Deleuze, como vimos, também pensam essas relaçóes que constituem a imagem fora, estritamente, do conjunto das imagens audiovisuais. Mesmo porque, os livros sobre o cinema năo apontam para uma história das imagens, mas para uma classificaçăo naturalista dos signos - năo no sentido, ainda, de uma "história natural" (RANCIÈRE, 2013, p. 115), mas de uma classificaçáo naturalista como a feita por Geoffroy Saint-Hilaire (LAPOUJADE, 2015, pp. 112-113). Por isso, sabendo dos limites da literatura e da própria palavra, da temporalidade específica que a literatura mobiliza, procuramos produzir um encontro dessas forças que atravessam o pensamento tanto de Deleuze quanto de Guattari para pensar como a máquina de Kafka faz delirar toda a obra de $O$ Processo.

Dito isto, é possível perceber nessa articulação entre a imagem-tempo e a máquina kafkiana o papel decisivo que o agenciamento concreto vai assumir no romance. Se ele se instala no próprio processo desmontagem é para, justamente, impedir que o tempo se forje linearmente, com um encadeamento necessário entre cenas, sequências e capítulos até recobrir inteiramente o livro. Náo fosse assim, 0 Processo rapidamente se encerraria sem que, para isso, mobilizasse tantos agentes para o funcionamento do tribunal e o seu próprio desenvolvimento espacial seria apenas configurado como um mero detalhe. Aliás, quanto à espacialidade da obra, Deleuze e Guattari (2003) dedicam um capítulo específico (Blocos, séries, intensidades) para cartografar essa construçâo em blocos que estăo em perpétua descontinuidade na obra de Kafka. Particularmente em $O$ Processo, há uma mudança entre dois estados, duas burocracias (a velha burocracia chinesa imperial despótica, como a vista em A Muralha da China, e a nova burocracia capitalista e socialista, de O Processo), duas posturas (absolviçăo aparente e adiamento ilimitado), dois modos, por fim, de instalaçăo no espaço: infinito-ilimitado-descontínuo, por um lado, e, por outro, finito-contíguo-intérmino (op. cit., p. 125). O próprio Kafka se situa na articulaçăo entre esses dois estados (op. cit., p. 128). Mais uma vez, a relaçăo literatura e vida se coloca na fabricaçăo da obra.

À toda essa construçâo espacial soma-se também, como uma carga virtual que lhe é subjacente, a força de desterritorializaçâo dos blocos que os coloca em perpétua descontinuidade:

Dado que os próprios blocos persistem, é necessário que eles mudem de forma, pelo menos, ao passar de um ponto de vista para outro. E, com efeito, se é verdade que cada bloco-segmento tem uma abertura ou uma porta sobre a linha do corredor, em geral bastante longe da porta ou da abertura do bloco seguinte, todos os blocos têm portas de trás que sâo contíguas. É a topografia mais surpreendente em Kafka, e que nâo é apenas uma topografia (mental): dois pontos diametralmente opostos revelamse caprichosamente em contato. Esta situaçăo encontra-se constantemente no Processo, em que K., ao abrir a porta de um cubículo muito perto do seu gabinete no banco, encontra-se num local de justiça onde săo punidos dois inspectores; ao visitar Titorelli (num subúrbio diametralmente oposto ao do tribunal), apercebe-se que a porta do fundo no quarto do pintor dá precisamente para os mesmos locais de justiça. [...] Dois blocos sobre uma linha contínua ilimitada, tendo portas muito afastadas uma da outra, têm, mesmo assim, portas de trás contíguas. E, ainda assim, 
estamos a simplificar [...] (op. cit., p. 126)

Em Linguagem e Literatura (2001), texto que condensa duas conferências de Foucault em Bruxelas, entre os dias 18 e 19 de março de 1964, sobretudo no segundo dia o problema do espaço na literatura se coloca a partir da análise literária. Observando a crítica moderna como a "repetiçâo do que há de repetível na linguagem" (FOUCAULT, 2001, p. 161), Foucault encontra duas direçóes para a análise literária: uma que diz respeito aos signos pelos quais as obras se designam a si próprias e a outra que diz respeito ao "modo como se especializa a distância que as obras tomam em relaçăo a si mesmas" (op. cit., p. 162). Para essa segunda direçăo, observa uma espacialidade referente à cultura (op. cit. pp. 169-170), uma referente ao interior da obra (op. cit., p. 170) e uma terceira que constituiria a espacialidade da própria linguagem da obra (op. cit., p. 171). Năo sem razăo, por isso, Deleuze e Guattari encontram uma espécie de topografia que constituiria os dois estados, e estes corresponderiam a duas burocracias, na obra de Kafka. De modo a permitir, segundo defendemos, que algo como uma imagem-tempo possa surgir ao impedir que haja uma fixaçấo da imagem por meio da representaçáo ou de qualquer elemento significante.

Dessa forma, o que o agenciamento póe em causa é o próprio vínculo sensório-motor, que está presente em uma narrativa verídica, para, a partir de suas engrenagens delirantes que promovem desterritorializaçóes, abrir-se às potências do falso. Com isso, é o próprio tempo que se libera do vínculo sensório-motor que antes o colocava de um determinado modo para dar passagem a um trabalho subterrâneo feito, primeiramente, pela expressăo. Já esse trabalho da expressăo enquanto matéria năo formada libera conteúdos puros, estabelecendo, entre o conteúdo e a expressáo, um vínculo que só é possível por sua năo-relaçăo. Ou seja, conteúdo e expressâo, assim como palavra e imagem, estăo de tal maneira próximos que a única coisa que há é distância: distância que promove uma separaçâo da imagem na palavra e da palavra na imagem. De modo que elas possam agora aparecer por si mesmas em toda a sua potência, como já notado por Deleuze a partir do enunciado em Foucault: de um lado, fala cega; do outro, visáo muda. Pois tudo em $O$ Processo é imanência. Mas imanência do desejo:

Numa primeira impressăo, é tudo falso no Processo: até a lei, contrariamente à lei kantiana, faz passar a mentira por regra universal. Os advogados sâo falsos advogados, os juízes săo falsos juízes, (advogados de văo-de-escada), (empregados vernais e desleais), ou, pelo menos, tăo subalternos que escondem as verdadeiras instâncias e (os tribunais de justiça inacessíveis) já năo se deixam representar. No entanto, se esta primeira impressăo năo é definitiva, é porque há uma força do falso e que náo é bom considerar a justiça em termos de verdadeiro ou de falso. A segunda impressáo é ainda muito mais importante: onde se julgava que havia lei, há, de facto, desejo e apenas desejo. A justiça é desejo, e năo lei. Com efeito, funcionário de justiça é toda a gente: nâo só os simples ouvintes, năo só os próprios padre e pintor, mas as raparigas equívocas e as meninas perversas que ocupam tanto espaço no Processo. (DELEUZE; GUATTARI, 2003, p. 89)

Tudo isso, porém, ainda năo nos deixa ver um problema ulterior de Kafka que vai ser a marca decisiva para que $O$ Processo năo reative, no limite, a metáfora. Trata-se do hiper-realismo, de sua poderosa sobriedade na escrita que vai se forjar numa postura ético-estético-política, marca de seu anti-estetismo. Dessa forma, ele procura "'agarrar o mundo' em vez de lhe extrair impressôes, trabalhar nos objetos, nas pessoas e 
nos acontecimentos, no próprio real e năo nas impressōes. Matar a metáfora" (op. cit., pp. 120 e 121). É essa força de sobriedade que impede que essas impressōes estéticas - como as personagens femininas etc. - se organizem por Necessidade, pois é o Acaso que constitui os pontos de ligaçăo entre as séries ou segmentos de $O$ Processo. Por isso, o trabalho de expressăo que promove o agenciamento concreto da máquina kafkiana nada tem a ver com estética ou com as personagens femininas ou personagens artistas (op. cit., p. 121). Há que se conceber uma máquina mais intensa que trabalha na dobradiça entre o molar e o molecular. Trata-se da máquina celibatária que está ligada imediatamente a um campo social por conexóes múltiplas (op. cit., p. 122). Uma "máquina tanto mais social e coletiva quanto mais celibatária e solitária" (op. cit., p. 123). Uma solidăo, nâo esqueçamos, que é povoada. Povoada por outras vozes e povos menores que sâo criados, mas que - e isso é preciso conceber - já estavam lá, pela enunciaçâo. É ela, a máquina celibatária, que dá acesso ao grito que corre $O$ Processo junto a outros gritos engendrados pelas máquinas, nas máquinas, e que constituem esse povo que falta e que a literatura faz passar (DELEUZE, 1997).

Há, portanto, muitas maneiras de se pensar em Kafka, de entrar em sua máquina de expressăo. A facilidade de entrar, contudo, é também o risco que nos acompanha: estamos sendo enganados? Difícil saber. K. é uma personagem que náo se deixa apanhar. Está sempre indo de um lugar para o outro, entrando em novas salas e lugares contíguos, levando adiante o seu processo. Mas K. é também essa figura estranha que agencia duas máquinas - autor e obra - e nos permite reafirmar a impossibilidade de dissociaçăo entre literatura e vida. Ainda assim, Kafka e K. nâo săo a "mesma pessoa". Se se agenciam, é porque há uma relaçâo diferencial que os coloca em jogo. É a força desse agenciamento que, inclusive, faz tanto K. quanto Kafka instalarem-se nesse projeto perverso pelo adiamento ilimitado. Há, porém, um sorriso. Difícil esquecê-lo. Um sorriso que se faz junto com O Processo, que destitui o outro polo do delírio de uma linguagem extensiva para o delírio bastardo de uma literatura menor. Esta é a dupla maquínica que faz fugir K. à regulaçaáo do double bind, numa tentativa de reedipianizaçâo pela linguagem: política e desejo.

A escrita em Kafka, o primado da escrita só significa uma coisa: de modo nenhum literatura, mas que a enunciaçấo constitui com o desejo uma só coisa, acima das leis, dos Estados e dos regimes. Enunciaçăo, no entanto, ela própria, sempre histórica, política e social. Uma micropolítica, uma política do desejo que póe em causa todas as instâncias. Nunca houve autor tăo cômico e alegre do ponto de vista do desejo; nunca houve autor mais político e social do ponto de vista do enunciado. Tudo é riso, a começar pelo Processo. Tudo é político, a começar pelas cartas a Felice. (DELEUZE; GUATTARI, 2003, p. 79) 


\section{Referências Bibliográficas}

DELEUZE, G. A imagem-movimento (Cinema 1). Traduçâo: Stella Senra. Săo Paulo: Brasiliense, 1983.

.(Cinema 2). Traduçăo: Eloisa de Araújo Ribeiro. Revisăo filosófica: Renato Janine Ribeiro. Sáo Paulo: Brasiliense, 2005.

Diferença e repetiçăo. Traduçáo: Luiz Orlandi e Roberto Machado. Rio de Janeiro: Graal, 1988.

. Foucault. Traduçấo: Claudia Sant'Anna Martins. Săo Paulo: Brasiliense, 2005.

Literatura e Vida. In: . Crítica e clínica. Traduçâo: Peter Pál Pelbart. Săo Paulo: 34, 1997.

DELEUZE, Gilles; GUATTARI, Félix. 0 Anti-Édipo: capitalismo e esquizofrenia 1. Traduçăo: Joana Moraes Varela e Manuel Maria Carilho. Lisboa: Assírio \& Alvim, 2004.

Kafka: para uma literatura menor. Traduçăo: e prefácio: Rafael Godinho. Lisboa: Assírio \& Alvim, 2003.

Mil platôs: capitalismo e esquizofrenia. Traduçăo: A. G. N. Neto et al. Săo Paulo: 34, 1996, v. 3.

0 que é a filosofia? Traduçăo: de Bento Prado Jr. e Alberto Alonso Muñoz. 3. ed. Sắo Paulo: 34, 2010.

FOUCAULT, Michel. Linguagem e literatura. In: MACHADO, Roberto. Foucault, a filosofia e a literatura. 2. ed. Rio de Janeiro: Jorge Zahar, 2001. pp. 137-175.

KAFKA, Franz. $O$ processo. Org., trad., pref, notas: Marcelo Backes. Porto Alegre: L\&PM, 2008.

LAPOUJADE, David. Deleuze, os movimentos aberrantes. Traduçăo: Laymart Garcia dos Santos. Săo Paulo: N-1, 2015.

PARENTE, André. Narrativa e modernidade - Os cinemas năo-narrativos do pósguerra. Traduçâo: Eloisa Araújo Ribeiro. Campinas: Papirus, 2000.

PLATÂO. OSofista. Traduçăo: Carlos Alberto Nunes, eBooks Brasil. 2003. Disponível em: <http://www.odialetico.hpg.ig.com.br>Acesso em: 13 maio 2017.

RANCIÈRE, Jacques. A fábula cinematográfica. Campinas: Papirus, 2013. 